to lay a firmer foundation for the criticism of his text; - to furnish reliable materials for English lexicography, which has, since the time of Samuel Johnson, increased in extent rather than in intrinsic value; - to set right, although only one, yet certainly the most prominent landmark in the history of the English language.

While the general reader will look for assistance in the definitions and explanations, scholars and critics will be soonest pleased, if satisfied by the exactness of the quotations. Therefore communications concerning errata will be extremely welcome.

Merely practical considerations prevailed in choosing the English language for the interpretations. No doubt the English of a German will often be found exceptionable and try the indulgence and kindness of the reader. But the author had no greater ambition, - if a lexicographer may be allowed to be ambitious - than to be useful also to born Englishmen.

Koenigsberg in Pr., Febr. 1874.

A. SCHMIDT.

\title{
Preface to the Second Volume of the First Edition.
}

The Appendix of this second volume will contain, besides what has been promised in the preface of the first, a list of the Shakespearian words forming the latter part in compositions, to meet a want not only felt by the author himself on many occasions, but intimated to him by some literary friends. In applying to it, it must always be borne in mind that it pretends to no higher claim than to be a supplement to this dictionary, and has no other object than to complete the quotations of the respective articles, by setting before the reader the whole range 
of evidence to be found in the works of the poet. For in very many cases the sense of simple words could not be distinctly ascertained except from their compounds. Wherever the boundary line between English and Latin or French composition was hardly discernible, it was thought better to do too much than too little.

One advantage, at least, was gained by the new revision of the whole vocabulary thus instituted. It led to the detection of some words - indexed on the next following leaf - that had been overlooked by the compiler, - a fault which, if nobody else, those at least will be inclined to pardon who ever have been engaged in a similar labour.

The reception the first volume has met with has been, in some respects, beyond the most sanguine expectations. The kind judgments passed on it by the most competent critics were indeed the more gratifying, as they did not, and could not possibly, touch the general design and tendency of the work, but turnod on details and the manner of treating particular questions. The justness and soundness of a method cannot be put to a better test than in its bearing on single points at issue. 'Assurance now is made double sure' that much that at first sight, and considered by itself, could not but seem objectionable, will be seen in another light, when in time the peculiar nature and the fundamental law of the whole will be fully perceived.

To make the poet his own interpreter, by discarding all preconceived opinions and subordinating all external means of information to those offered by himself, was throughout the leading principle of the work. What Aristarchus once did for Homer, and Galen for Hippocrates, was yet to be done for Shakespeare. We beg to refer the reader to an extract from Galen's praef. voc. Hippocr. quoted in Professor Lehrs'

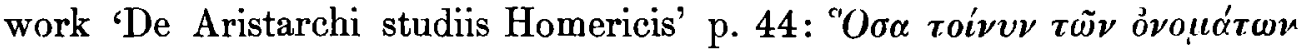

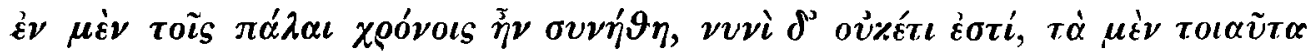

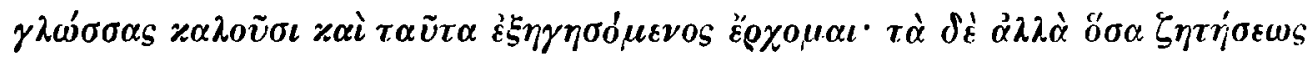

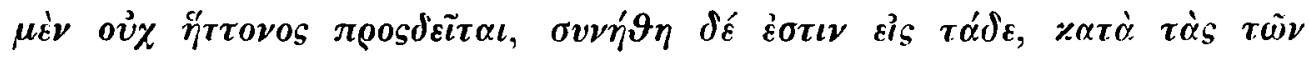

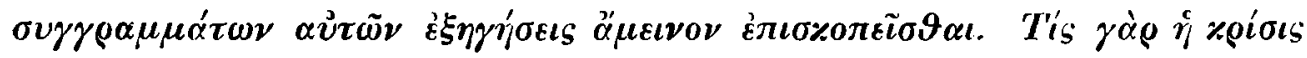

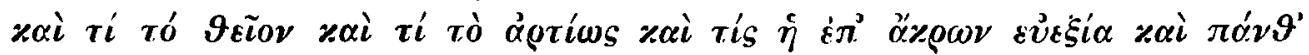

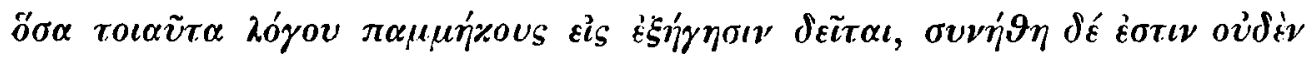

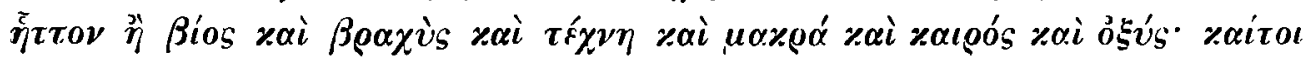




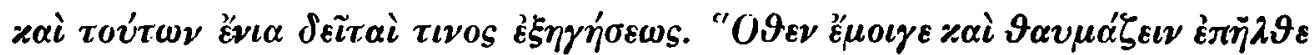

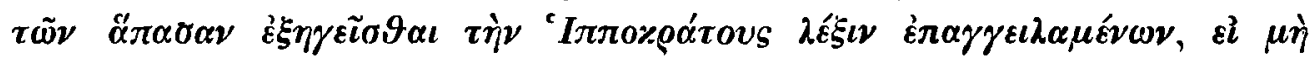

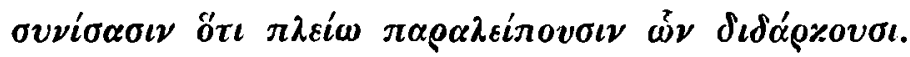

To this Prof. Lehrs observes: Haec omnia primus intellexit in Homero et praestitit Aristarchus. Quare non scripsit glossas, sed in continua poetae interpretatione accuratissime versatus est, in consuetis vocabulis, quorum et ad majorem Homericorum locorum partem plerumque pertinet utilitas et explicatio certior, plus etiam quam in rarioribus et antiquitate obscuratis operae ponens et ne quid praetermittatur verbum verbo reddens. Abjecit illas doctrinae sarcinas, non tam existimans, ex aliis scriptoribus multa ad Homerum illustrandum promi posse quam cavendum esse ne aliorum consuetudine temere ad poetam translata imprudentes in vitia et errores incurramus.

Let us subjoin, for the use of Shakespearian text-emendators, a few more citations from the same work:

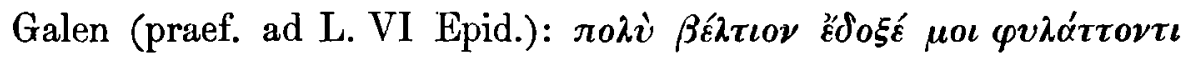

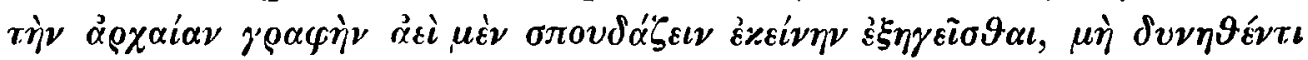

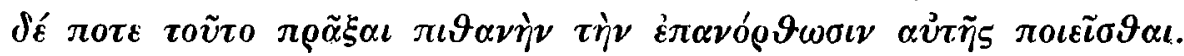

Quintilian (Instit. orat. IX, 4, 39): Quaedam in veteribus libris reperta mutare imperiti solent et, dum librariorum insectari volunt inscientiam, suam confitentur.

Lehrs (p. 358): Ars critica primum elaborat ut scriptores, quos pauci mss. corruptos exhibent, sine summa offensione legi possint; partim imperfecta ars multa non intelligit inscientia, quae tollit ne quid relinquatur quod absurdum esse putat. Sed gliscentibus studiis, codicibus pluribus paratis, rerum sermonisque scientia vulgata, arte interpretandi exculta, multis obscurioribus locis per variorum tentamina tandem reclusis, in arctiores se fines contrahit, et quo magis primi magistri peccaverunt, e magis jam ipso contradicendi studio ad fontes suos revertitur.

Koenigsberg Pr., Oct. 1875.

A. S. 